\title{
Hyaluronate and type III procollagen peptide concentrations in bronchoalveolar lavage fluid as markers of disease activity in farmer's lung
}

\author{
LEIF BJERMER, ANNA ENGSTRÖM-LAURENT, RUNE LUNDGREN, LEIF ROSENHALL, \\ ROGER HÄLLGREN
}

\begin{abstract}
Ten patients were studied during an acute episode of farmer's lung. Prominent findings were an impaired diffusion capacity (on average only $51 \%$ of predicted) and substantially increased amounts of hyaluronate and type III procollagen peptide recovered during bronchoalveolar lavage; mean concentrations of these constituents in lavage fluid were 547 (range 137-1125) and $9.7(2.8-19.4) \mu \mathrm{g} /$, respectively. In bronchoalveolar lavage fluid from healthy controls $(n=21)$ hyaluronate concentrations were less than $15 \mu \mathrm{g} / \mathrm{l}$ and procollagen peptide concentrations less than $0.2 \mu \mathrm{g} / \mathrm{l}$. Lavage fluid concentrations of these potential markers of fibroblast activation declined during the recovery phase of farmer's lung; four to 10 weeks after admission $(n=7)$ mean concentrations of hyaluronate and procollagen peptide were 154 (range 38-650) and 4.4 (0.6-15.8) $\mu \mathrm{g} / 1$, respectively. At clinical remission six to 14 months after admission concentrations of these markers had returned almost to normal, though slightly increased concentrations were still evident in about half the patients $(n=7)$. At that time lung volumes were normal but diffusion capacity remained slightly subnormal.

It was concluded that in farmer's lung release of hyaluronate and type III procollagen peptide reflects activity of the disease. Increased synthesis of these connective tissue components
\end{abstract}

Department of Pulmonary Medicine, University Hospital, Umeå, Sweden LEIF BJERMER, MD, research fellow in pulmonary medicine

RUNE LUNDGREN, MD, PHD, associate professor of pulmonary medicine

LEIF ROSENHALL, MD, PHD, associate professor of pulmonary medicine

Department of Internal Medicine and the Institute of Medical and Physiological Chemistry, the Biomedical Centre, Uppsala, Sweden ANNA ENGSTRŌM-LAURENT, MD, PHD, senior registrar in rheumatology ROGER HÂLLGREN, MD, PHD, associate professor of internal medicine

Correspondence and requests for reprints to: Dr Hällgren. continuing in a patient avoiding mouldy plant material may signal an increased risk of developing fibrotic lung disease. The abnormal accumulation of hyaluronate in the smaller airways in acute farmer's lung may be expected to immobilise water and thereby provide a possible mechanism of the interstitial inflammatory lung oedema with associated impaired gas diffusion. This hypothesis is supported by the relation found between hyaluronate in lavage fluid and reduced diffusion capacity.

\section{Introduction}

Farmer's lung is a form of extrinsic alveolitis that results from intense exposure to mouldy plant material. The prevalence of farmer's lung varies with geographical area from $0 \cdot 4 \%$ to $5.0 \%$ of the farming population. ${ }^{12}$ Avoiding the offending agent will in most cases solve the medical problem. Nevertheless, interstitial fibrosis with irreversible pulmonary damage may develop after several attacks of the disease but also after a single, severe attack, ${ }^{3}$ occasionally leading to death. ${ }^{34}$ Hence doctors may be faced with needing to advise certain people who have had an acute attack to give up farming when continued contact with plant material may not necessarily lead to progressive respiratory failure ${ }^{46} \mathrm{Clinical}$ and laboratory tests are therefore urgently needed that will identify the population at risk of developing the chronic fibrotic stage of the disease.

In a previous series we found that patients with sarcoidosis have increased hyaluronate concentrations in bronchoalveolar lavage fluid. ' We concluded that in sarcoidosis release of hyaluronate into the airways is related to the lung volume and therefore possibly to the course of the disease. The findings suggested that increased synthesis of hyaluronate in lung parenchyma may reflect activation or proliferation of lung fibroblasts. Another potential marker of fibroblast activation is type III procollagen peptide, ${ }^{89}$ which also appears in increased concentrations in lavage fluid in sarcoidosis ${ }^{10} 11$ and correlates with clinical signs of lung fibrosis. ${ }^{11}$ In an attempt to detect fibroblast activation in patients with farmer's lung we have therefore measured hyaluronate and type III procollagen peptide 
concentrations in their lavage fluid during the acute stage of the disease and also during the recovery phase and at clinical remission. We related the findings to radiological changes and measures of pulmonary function.

\section{Patients and methods}

Ten non-smoking dairy farmers (five men, five women) aged 33-65 were admitted to hospital with a history of chills, fever, dyspnoea, and cough related to exposure to mouldy hay or straw. Exposure was confirmed by the precipitin test or spore measurements. ${ }^{12}$ All were dysponeic on admission and had fine inspiratory rates. Diffuse parenchymal infiltrates without adenopathy seen in chest $x$ ray films and lung function profiles were also compatible with allergic alveolitis. Twenty one apparently healthy nonsmoking volunteers (14 men, seven women) aged 19-61 served as controls.

Vital capacity and forced expiratory volume in one second were measured with a Bernstein spirometer and diffusion capacity (carbon monoxide transfer factor) determined by the single breath carbon monoxide technique. Results were expressed as the percentage of predicted normal. ${ }^{13} 14$

Before bronchoscopy patients and controls were given atropine or hyoscine usually combined with morphine or pethidine chloride subcutaneously. The upper respiratory tract was anaesthetised with lignocaine hydrochloride. A fibreoptic bronchoscope (Olympus BF IT or BF 4B2; Tokyo) was wedged in the lingular segmental bronchus and $240 \mathrm{ml}$ sterile Krebs-Ringer phosphate buffer $\mathrm{pH} 7 \cdot 3,37^{\circ} \mathrm{C}$, infused in boluses of $60 \mathrm{ml}$. The fluid was gently aspirated immediately after each instillation. The lavage fluid was kept on ice and passed through a nylon filter (pore diameter $100 \mu$; Syntab Products AB, Malmö, Sweden). After centrifugation at $400 \mathrm{~g}$ for five minutes the supernatant was kept frozen until analysis in sequence. Hyaluronate was analysed in duplicate in serum and lavage fluid by a radioassay, as described. ${ }^{71}$ The normal concentration of hyaluronate in serum $(n=80)$ is 49 (SD 33) $\mu \mathrm{g} / \mathrm{l}$. Type III procollagen peptide was analysed in duplicate in serum and lavage fluid by radioimmunoassay. ${ }^{11}$ The detection limit for hyaluronate is $5 \mu \mathrm{g} / \mathrm{l}$ and for procollagen peptide $0.2 \mu \mathrm{g} / \mathrm{l}$. When either was undetectable the detection limit was used in the calculations. In our laboratory the normal serum concentration of procollagen peptide ( $n=$ 111 ) is 15.4 (SD 2.2) $\mu \mathrm{g} / \mathrm{l}$. Variability of the measurements of hyaluronate and procollagen was less than $10 \%$. Albumin was measured by fluorescence nephelometry (Multistat III; Instrumental Laboratory, Lexington, MA) at the department of clinical chemistry, University Hospital of Uppsala.

Because of the skewed distribution of hyaluronate and procollagen peptide in lavage fluid ${ }^{116}$ we used log transformed data to calculate means and non-parametric tests (Wilcoxon's paired rank sum test and Spearman's rank correlation test) for the statistical analyses. The log transformed values were normally distributed. Means are presented as the antilog values.

The study was performed according to the Declaration of Helsinki and with free and informed consent of all volunteers and patients.

\section{Results}

On first admission all 10 patients had clinically active alveolitis and interstitial changes in chest radiographs. Impaired lung function was shown by reduced vital capacity ( $80 \%$ (SEM $6 \%$ ) of predicted), reduced forced expiratory volume in one second $(81 \%(4 \%))$, and considerably reduced diffusion capacity $(51 \%(3 \%)$ ) (table I). The impaired lung function was associated with hypoxaemia (mean pressure of arterial oxygen $7 \cdot 6$ (SEM 0.4) $\mathrm{kPa})$.

At the initial investigation nine patients had bronchoalveolar lavage; one patient was too ill. Concentrations of hyaluronate and procollagen peptide in the lavage fluid were on average 547 (range 137-1125) and 9.7 (2.8-19.4) $\mu \mathrm{g} / \mathrm{l}$, respectively (table II). In healthy controls we were previously unable to find measurable concentrations of hyaluronate-that is, $\geqslant 5 \mu \mathrm{g} / 1$-in lavage fluid $(n=17) .^{7}$ In this study, in a separate control group of 21 apparently healthy men and women, 14 had hyaluronate concentrations above the detection limit. The highest value was 15 (SD 2) $\mu \mathrm{g} / 1$, and this was therefore taken as the upper limit of normal in this study. Procollagen peptide concentrations were below the detection limit $(0 \cdot 2 \mu \mathrm{g} / 1)$ in all the controls. Serum concentrations of hyaluronate and procollagen peptide were normal in all patients. To test for increased permeability across the capillary-alveolar barrier we looked for raised albumin concentrations in bronchoalveolar lavage fluid; the mean concentration was on average about three times higher than the upper limit of normal (figure).

Seven patients were reinvestigated four to 10 weeks after their first admission. In only two had the chest $x$ ray appearances returned to normal in both cases after treatment with steroids. Overall the concentrations of hyaluronate and procollagen in the bronchoalveolar lavage fluid had fallen $(p<0.01)$ but were still above normal; mean values were 154 (range 38-650) and $4.4(0 \cdot 6-15 \cdot 8) \mu \mathrm{g} / \mathrm{l}$, respectively (table II). Diffusion capacity was improved and lung volumes were in the lower range of normal (figure; table I). At the third follow up, six to 14 months after admission all patients investigated $(n=7)$ had normal chest $x$ ray appearances and no symptoms of lung disease. None of the patients were given corticosteroids at that stage. Hyaluronate and procollagen peptide concentrations were further reduced $(p<0.001)$ but remained above normal in four and three patients, respectively (table III). Lung volumes were normal but diffusion capacity was still impaired in two patients (table III). During follow up albumin concentrations in broncheoalveolar lavage fluid returned to normal (figure; table II).

There was a strong association between hyaluronate and procollagen peptide concentrations in bronchoalveolar lavage fluid $(r=0.93 ; p<0.001)$. These variables were not related to concentrations of albumin in the fluid. The hyaluronate concentration was related to diffusion capacity $(r=-0.77$; $p<0.001)$ but not to lung volume $(p>0.05)$ (hyaluronate concentration $v$ vital capacity, $r=-0 \cdot-26$; hyaluronate concentration $v$ forced expiratory volume in one second, $r=-0.35$ ). Procollagen peptide was related to a similar degree as hyaluronate to diffusion capacity $(r=-0.78 ; \mathrm{p}<0.001)$ but was not related to vital capacity $(r=-0.28)$ or forced expiratory volume in one second $(r=-0 \cdot 26)$.

TABLE I-Pulmonary function values on admission and during follow up

\begin{tabular}{|c|c|c|c|c|c|c|c|c|c|c|c|c|c|}
\hline & \multirow{2}{*}{$\begin{array}{c}\text { No of } \\
\text { patients }\end{array}$} & \multicolumn{4}{|c|}{ Vital capacity (\% of predicted) $)^{\star}$} & \multicolumn{4}{|c|}{$\begin{array}{l}\text { Forced expiratory volume in one second } \\
\text { (\% of predicted }) \dagger\end{array}$} & \multicolumn{4}{|c|}{ Diffusion capacity (\% of predicted) $\ddagger$} \\
\hline & & Mean & SEM & SD & Range. & Mean & SEM & SD & Range & Mean & SEM & SD & Range \\
\hline $\begin{array}{l}\text { On admission } \\
4-10 \text { Weeks after admission } \\
\text { 6-14 Months after admission }\end{array}$ & $\begin{array}{r}10 \\
7 \\
7\end{array}$ & $\begin{array}{l}80 \\
86 \\
93\end{array}$ & $\begin{array}{l}6 \\
3 \\
4\end{array}$ & $\begin{array}{r}18 \\
8 \\
11\end{array}$ & $\begin{array}{l}55-108 \\
76-95 \\
80-106\end{array}$ & $\begin{array}{l}81 \\
91 \\
96\end{array}$ & $\begin{array}{l}4 \\
2 \\
5\end{array}$ & $\begin{array}{r}11 \\
5 \\
12\end{array}$ & $\begin{array}{l}65-93 \\
87-102 \\
81-116\end{array}$ & $\begin{array}{l}51 \\
66 \\
81\end{array}$ & $\begin{array}{l}3 \\
4 \\
4\end{array}$ & $\begin{array}{r}8 \\
11 \\
10\end{array}$ & $\begin{array}{l}40-63 \\
52-84 \\
61-89\end{array}$ \\
\hline
\end{tabular}

$\star_{\text {Reference value }} \geqslant 80 \%$.

Reference value $\geqslant 80 \%$.

$\dagger$ Reference value $\geqslant 80 \%$.
$\ddagger$ Reference value $\geqslant 75 \%$.

TABLE II-Hyaluronate, procollagen peptide, and albumin concentrations in bronchoalveolar lavage fluid on admission and during follow up

\begin{tabular}{|c|c|c|c|c|c|c|c|c|c|c|c|c|c|}
\hline \multirow[t]{2}{*}{. } & \multirow{2}{*}{$\begin{array}{c}\text { No of } \\
\text { patients }\end{array}$} & \multicolumn{4}{|c|}{ Hyaluronate $(\mu \mathrm{g} / 1)^{\star}$} & \multicolumn{4}{|c|}{ Procollagen peptide $(\mu \mathrm{g} / \mathrm{l}) \dagger$} & \multicolumn{4}{|c|}{ Albumin (mg/l)‡ } \\
\hline & & Mean & SEM & SD & Range & Mean & SEM & SD & Range & Mean & SEM & SD & Range \\
\hline $\begin{array}{l}\text { On admission } \\
4-10 \text { Weeks after admission } \\
\text { 6-14 Months after admission }\end{array}$ & $\begin{array}{l}9 \\
7 \\
7\end{array}$ & $\begin{array}{r}547 \\
154 \\
18\end{array}$ & $\begin{array}{c}401-745 \\
107-220 \\
14-22\end{array}$ & $\begin{array}{c}228-1309 \\
60-397 \\
9-33\end{array}$ & $\begin{array}{l}137-1125 \\
38-650 \\
\leqslant 5-35\end{array}$ & $\begin{array}{l}9 \cdot 7 \\
4 \cdot 4 \\
0 \cdot 4\end{array}$ & $\begin{array}{l}7 \cdot 3-12 \cdot 9 \\
2 \cdot 9-6 \cdot 5 \\
0 \cdot 3-0 \cdot 6\end{array}$ & $\begin{array}{l}4 \cdot 4-21 \cdot 7 \\
1 \cdot 5-12 \cdot 3 \\
0 \cdot 2-1 \cdot 0\end{array}$ & $\begin{aligned} & 2 \cdot 8-19 \cdot 4 \\
0 \cdot 6-15 \cdot 8 & \\
\leqslant & 0 \cdot 2-2 \cdot 7\end{aligned}$ & $\begin{array}{r}313 \\
140 \\
96\end{array}$ & $\begin{array}{l}53 \\
50 \\
15\end{array}$ & $\begin{array}{r}151 \\
130 \\
39\end{array}$ & $\begin{array}{r}122-561 \\
38-468 \\
50-168\end{array}$ \\
\hline
\end{tabular}

${ }^{\star}$ Reference value $\leqslant 15 \mu \mathrm{g} /$.

tReference value $\leqslant 0 \cdot 2 \mu \mathrm{g} /$

$\ddagger$ Reference value $\leqslant 90 \mathrm{mg} /$. 
TABLE III-Pulmonary function and bronchoalveolar lavage concentrations of hyaluronate, procollagen peptide, and albumin in patients with farmer's lung at clinical remission

\begin{tabular}{|c|c|c|c|c|c|c|}
\hline Case No & $\begin{array}{l}\text { Vital capacity } \\
\text { (\% of predicted) }\end{array}$ & $\begin{array}{l}\text { Forced expiratory volume } \\
\text { in one second } \\
\text { (\% of predicted) }\end{array}$ & $\begin{array}{l}\text { Diffusion capacity } \\
\text { (\% of predicted) }\end{array}$ & Hyaluronate $(\mu \mathrm{g} / \mathrm{l})$ & $\begin{array}{l}\text { Procollagen peptide } \\
\qquad(\mu g / 1)\end{array}$ & $\underset{(\mathrm{mg} / \mathrm{l})}{\text { Albumin }}$ \\
\hline $\begin{array}{l}1 \\
2 \\
3 \\
4 \\
5 \\
6 \\
7\end{array}$ & $\begin{array}{r}80 \\
81 \\
102 \\
83 \\
106 \\
98 \\
99\end{array}$ & $\begin{array}{r}81 \\
87 \\
100 \\
85 \\
116 \\
105 \\
102\end{array}$ & $\begin{array}{l}77 \\
79 \\
86 \\
61 \\
83 \\
71 \\
89\end{array}$ & $\begin{array}{r}35 \\
\leqslant 5 \\
26 \\
18 \\
28 \\
8 \\
15\end{array}$ & $\begin{array}{r}0.6 \\
\leqslant 0.2 \\
\leqslant 0.2 \\
0.5 \\
2.7 \\
\leqslant 0.2 \\
\leqslant 0.2\end{array}$ & $\begin{array}{r}85 \\
50 \\
168 \\
61 \\
90 \\
107 \\
108\end{array}$ \\
\hline Reference value & $\geqslant 80$ & $\geqslant 80$ & $\geqslant 75$ & $\leqslant 15$ & $\leqslant 0.2$ & $\leqslant 90$ \\
\hline
\end{tabular}
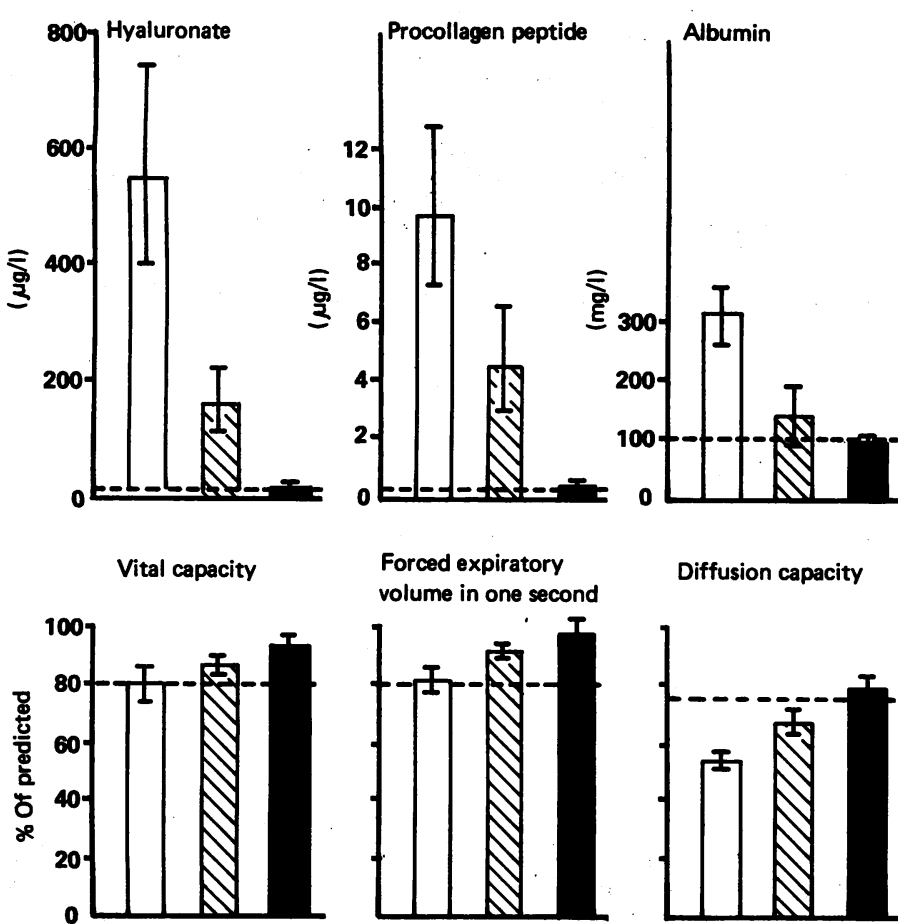

Forced expiratory volume in one second
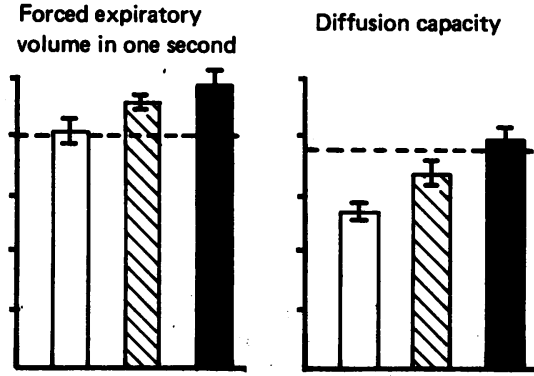

Mean bronchoalveolar lavage concentrations of hyaluronate, procollagen peptide, and albumin and mean lung function values in patients with various stages of farmer's lung. Bars are SEM. $\square$ Values in 10 patients on admission with acute symptoms. Values $(n=7)$ during recovery phase 4-10 weeks after admission. Values $(n=7)$ at clinical remission 6-14 months after admission. - - - Upper normal ranges for constituents in lavage fluid; lower normal ranges for lung function values.

\section{Discussion}

The main findings of this study were the very high concentrations of hyaluronate and type III procollagen peptide recovered in bronchoalveolar lavage fluid from patients with active farmer's lung. Concentrations were on average about 50 times higher than in healthy controls and roughly 10 times higher than in a large group of patients with sarcoidosis. ${ }^{16}$ The contribution of hyaluronate from the plasma compartment to the alveolar space may be overlooked, as patients with farmer's lung, like those with sarcoidosis, ${ }^{16}$ have normal serum hyaluronate concentrations. In both series concentrations of hyaluronate in the lavage fluid greatly exceeded those in the circulation. In contrast, the lavage fluid concentrations of procollagen peptide in the patients with farmer's lung were close to circulating concentrations, and therefore procollagen recovered during lavage might theoretically have been influenced by increased passive permeability across the capillary-alveolar barrier. An abnormal interstitial alveolar permeability or impaired elimination from alveolar interstitial tissue due to affected lymph drainage, for example, must be considered as another possible influence in the appearance of increased quantities of interstitial constituents in bronchoalveolar secretions.

That our patients had a considerably reduced diffusion capacity as the most obvious sign of impaired lung function agrees with other studies. ${ }^{56}$ After avoiding contact with mouldy hay the clinical condition rapidly improved. Nevertheless, lung diffusion capacity remained impaired during the first months after the acute phase and was slightly subnormal six to 14 months later. Thus impaired lung function remained despite subjective and radiological return to normal. The finding that pulmonary function stabilises at subnormal values has also been reported. ${ }^{6}$ During follow up lavage concentrations of hyaluronate and procollagen peptide began to return to normal in parallel with improved pulmonary function. Six to 14 months after the initial investigations, however, over half of the patients had increased lavage concentrations of these markers.

The pathogenesis of the inflammatory response in allergic alveolitis remains unclear but probably includes both immune complex induced reactions and cell mediated responses in the lung. ${ }^{17-20}$ Histopathologically a chronic interstitial and alveolar inflammation is seen together with a granulomatous response. ${ }^{21}$ In experimental allergic alveolitis in animals the late mononuclear infiltration of the lung parenchyma is accompanied by interstitial fibrosis. ${ }^{22}$ Hence it seems reasonable to consider activated alveolar macrophages as partly responsible for fibroblast activation in allergic alveolitis in man. Alveolar macrophages produce factors which stimulate fibroblasts in vitro. ${ }^{2324}$ Whether these macrophage derived components may also induce an enhanced hyaluronate synthesis in pulmonary fibroblasts has not been tested; other fibroblast proliferating substances-for example, derived from platelets -induce enhanced hyaluronate synthesis in fibroblasts. ${ }^{25}$ The finding that procollagen peptide concentrations were closely related to hyaluronate concentrations is further evidence that activated fibroblasts are a main source to increased hyaluronate production in the lung in farmer's lung.

The very high concentrations of hyaluronate recovered in lavage fluid during the acute attack of farmer's lung must be considered as one factor behind the inflammatory interstitial oedema. Hyaluronate is important in water homoeostasis in the tissues; it attracts water by osmotic forces and resists water flow. ${ }^{26}$ These unique properties of hyaluronate are utilised in eye surgery. In lung tissue an excessive accumulation of hyaluronate may be expected to immobilise water and make the lung more rigid and thereby impair gas diffusion over the alveolar membrane. This hypothesis, based on the physicochemical properties of hyaluronate, has been further supported by the direct detection of hyaluronate accumulation in the alveolar interstitial tissue in bleomycin induced alveolitis in rats (Hällgren et al, unpublished observations). Our finding that the reduced diffusion capacity in farmer's lung was related to the lavage hyaluronate concentration provides indirect support for the hypothesis.

The prognostic value of measuring fibroblast markers in lavage fluid has not been explored in this study. Nevertheless, increased lavage concentrations of hyaluronate or procollagen suggest persistent fibroblast activation or an increased fibroblast mass. In sarcoidosis follow up studies have supported the value of the hyaluronate concentration as a prognostic marker (Bjermer et al, 
unpublished). Patients with laboratory signs of altered synthesis of connective tissue components should be considered as a potential risk group for developing lung fibrosis during continued contact with the offending agent.

This study was supported by grants from the Swedish Medical Research Council, the Swedish Association against Chest and Lung Diseases, and the Pharmacia Research Foundation.

\section{References}

1 Gruchow HW, Hoffman RG, Marx JJ, Emanuel DA, Rim AA. Precipitating antibodies to farmer's lung antigen in a Wisconsin farming population. Am Rev Respir Dis 1981;124:411-5.
Morgan DC, Smyth JT, Lister RW. Chest symptoms in farming communities with special Morgan DC, Smyth JT, Lister RW. Chest symptoms in
reference to farmer's lung. Brf Ind Med 1975;32:228-34.

3 Hapke EJ, Seal RME, Thomas GO. Farmer's lung: a clinical, radiographic and serological correlation of acute and chronic stages. Thorax 1968;23:451-68.

4 Barbee RA, Callies Q, Dickie HA, Rankin J. The long-term prognosis in farmer's lung. Am Reo Respir Dis 1968;97:223-31.

5 Braun SR, de Pico GA, Tsiatis A, Horvath E, Dickie HA, Rankin J. Farmer's lung disease: longterm clinical and physiologic outcome. Am Rev Respir Dis 1979;119:185-91.

6 Cormier Y, Bellanger J. Long-term physiologic outcome after acute farmer's lung. Chest 1985;87:796-800.

7 Hällgren R, Eklund A, Engström-Laurent A, Schmekel B. Hyaluronate in bronchoalveolar lavage fluid: a new marker in sarcoidosis reflecting pulmonary disease. Br Med f 1985;290:1778-81.

8 Miller EJ. Biochemical characteristics and biological significance of the genetically-distinct collagens. Mol Cell Biochem 1976;13:165-92.

9 Rohde H, Vargas L, Hahn E, Kalbfleich H, Bruguera M, Timpl R. Radioimmunoassay for type III procollagen peptide and its application to human liver disease. Eur f Clin Invest 1979;9: 451-9.

10 Low RB, Cutroneo KR, Davis GS, Giancola MS. Lavage type III procollagen N-terminal peptides in human pulmonary fibrosis and sarcoidosis. Lab Inoest 1983;48:755-9.
11 Bjermer L, Thunell M, Hällgren R. Procollagen III peptide in bronchoalveolar lavage fluid: a potential marker of altered collagen synthesis reflecting pulmonary disease in sarcoidosis. Lab Invest 1986;55:654-6.

12 Blomquist G, Palmgren U, Strōm G. Improved techniques for sampling fungal particles in highly contaminated environments. Scand $\mathcal{f}$ Work Environ Health 1984;10:253-8.

13 Berglund E, Birath G, Bjure J, et al. Spirometric studies in normal subjects. Acta Med Scand 1963;1:185-206.

14 Hinshaw HC, Murray JF, eds. Diagnostic procedures. Respiratory physiology and respiratory function testing. In: Disease of the chest. Philadelphia: W B Saunders Co, 1980;141-2.

15 Engström-L aurent A Laurent UBG, Lilia K, Laurent TC. Concentration of sodium hyaluronate in serum. Scand $\mathcal{F}$ Clin Lab Invest 1985;45:497-504.

16 Bjermer L, Engström-Laurent A, Thunell M. Hällgren R. Hyaluronic acid in bronchoalveolar lavage fluid in patients with sarcoidosis. The relationship to lavage mast cells. Thorax (in press). 17 Roberts RC, Moore VL. Immunopathogenesis of hypersensitivity pneumonitis. Am Rev Respir Dis 1977;16:1075-90.

18 Ghose $T$, Laudrigan $P$, Killeen $R$. Immunopathological studies in patients with farmer's lung. Clin Allengy 1974;4:119-29.

19 Fournier E, Tonnel AB, Gosset P, Wallaert B, Ameisen JC, Voisin C. Early neutrophil alveolitis after antigen inhalation in hypersensitivity pneumonitis. Chest 1985;88:563-6.

20 Costabel U, Bross KJ, Rühle KH, Löhr GW, Matthys H. Ta-Like antigens on T-cells and their subpopulations in pulmonary sarcoidosis and in hypersensitivity pneumonitis. Am Rev Respir Dis 1985;131:337-42.

21 Sutinen S, Reijula K, Huhti E, Kärkölâ P. Extrinsic allergic bronchioloalveolitis: serology and biopsy findings. Eur $\mathcal{F}$ Respir Dis 1983;64:271-82.

22 Bernardo J, Hunninghake GW, Gadek JE, Ferrans VJ, Crystal RG. Acute hypersensitivity pneumonitis serial changes in lung lymphocyte subpopulations after exposure to antigen. $A m$ Reo Respir Dis 1979;120:984-94.

23 Hunninghake GW. Release of interleukin-1 by alveolar macrophages of patients with active pulmonary sarcoidosis. Am Reo Respir Dis 1984;129:569-72.

24 Bitterman PB, Rennard SI, Hunninghake GW, Crystal RG. Human alveolar macrophage growth factor for fibroblasts. Regulation and partial characterization. 7 Clin Invest 1982;70:806-22.

25 Engström-Laurent A, Feltelius N, Hällgren R, Wasteson A. Raised serum hyaluronate levels in scleroderma: an effect of growth factor induced activation of connective tissue cells? Ann $R$ heum Dis 1985;44:614-20.

26 Comper WD, Laurent TC. Physiological function of connective tissue polysaccharides. Physiol Rev 1978;58:255-315.

(Accepted 6 August 1987)
Dr W Allen Sturge writes to us as follows:-To the medical man the studies afforded by the earthquake shocks, to which we have recently been subjected on the Riviera, have been interesting in the psychical rather than the more strictly medical aspects. We have had presented to us a curious and very interesting study of panic-panic prolonged, and with a future of uncertainty. It has brought out the real character of people more, perhaps, than anything else could have done; has suddenly plumbed the depths or the shallows, as it may be, of their nature; and in one moment has shown which was real solid material and which was mere veneer. People rushed from their hotels, and, in not a few cases from the town in which they were at the time, minus wigs, teeth, and all the various improvers of their attire. All this has been told many times over in the daily papers; but I have not found that much has been said of the other artificial make believes that were left behind in the hotel bed rooms-courage, coolness, self restraint, thought for others, common sense-all of which qualities would doubtless, on the previous day, have been claimed as their own by each one of the motley crowd that paid high prices to the cabmen to take them off as hard as they could drive to the railway station, and who, by their own showing, fought and elbowed their way to the ticket-offices, with no thought for the large aged and invalid population that would require the help of the strong; careful only that they personally should stand no chance of danger. The spectacle was not an edifying one. It was, I suppose, to be expected; but what one would scarcely have expected to see, was the bold face put upon their proceedings by the fugitives; the assumption that there could be nothing to be ashamed of in this wild stampede; the careful description of their doings in signed letters to the papers.

Fortunately for humanity, this was not the only aspect of the panic. For this side one can feel little but contempt, and we will pass it by without further word. It is a more grateful task to speak of those who, equally frightened, and in many instances unnerved, maintained their self-control, faced the possibilities of danger, and, while doing what they could to minimise their personal risk-as all are in duty bound to do-cheerfully accepted the situation, and sought in what way they could be of assistance to others. I am not going to say that any very great amount of heroism was required to do this rather obvious duty; indeed, one would have thought that it was only such as might have been found in most men and women. The event, as we have seen, proved the contrary; but I am glad to be able to record that there were very many exceptions to the rule of sauvc qui peut, and in not a few instances there was something very like real heroism. The behaviour of many of the invalids was admirable. A paralysed lady-patient of mine, living on the second story of a some-what rickety house, elected to remain in bed, rather than run the risks of exposure out of doors; and she alone stayed in the house on the following night, with the certain knowledge that she would be out of the reach of help in case of any renewal of the shocks. This was done in no spirit of foolhardiness, but with a full appreciation of the consequences, and after careful weighing of the certain risks against the problematical; but none the less did it require a high degree of moral courage to pass through that solitary night in the panic-stricken town. A young lady recovering from pneumonia quietly remained with her nurse on the fifth story of a large hotel-the only occupant of the upper stories - until my visit, and was quite prepared, if told to do so, to stay where she was. I could give many instances of a similar kind, where persons helpless from age or infirmity remained calm and collected under very trying circumstances. Some of the nervous invalids were, indeed stimulated by the presence of danger, acquired temporary strength in the midst of the weakness of others, and, far from being thrown back by the shock, seemed for the time to be improved in health. With them, however, as with very many others who kept up at the time, there has been a period of reaction, with which the medical men have not to contend. The only treatment for this condition is, in most cases, to send the patients away from the scene where they experienced the shock. Sleep, which has refused to return as long as they are in the bed where they had their fright, comes back as soon as they have made a slight change. People have become extraordinarily sensitive to earth-tremors. Of these we have had a considerable number, most of them very slight; but the slightest movement of the bed suffices in the case of many nervous people to wake them up with a frightened start; and a dream of earthquakes is, as might be supposed, a common form of nightmare.

Of actual disease induced by exposure there is less than might have been expected. Many colds were, of course, caught, but few were of a severe nature. Physicians at Mentone will probably have a sadder tale to tell in this respect than we have at Nice from our personal experience. I am glad to say that my patients came through the very trying ordeal very much better than I could have expected.

(British Medical foumal 1887;i:643.) 